\title{
Comparison of the Bioactive Secondary Metabolites from the Scale Insect Pathogens, Anamorph Paecilomyces cinnamomeus, and Teleomorph Torrubiella luteorostrata
}

\author{
Masahiko Isaka, Somporn Palasarn, Kanokarn Kocharin, Nigel L. Hywel-Jones
}

Received: June 14, 2007 / Accepted: September 3, 2007

(C) Japan Antibiotics Research Association

\begin{abstract}
A scale insect pathogen Paecilomyces cinnamomeus BCC 9616 and its teleomorph Torrubiella luteorostrata BCC 9617, collected on the same host specimen, were fermented and chemically explored. Both fungi produced paecilodepsipeptide A (1) and zeorin (4) as major constituents of mycelia extracts. The culture broth extract of BCC 9616 provided a known diketopiperazine, terezine D (5), and a new xanthone glycoside, norlichexanthone-6- $O-\beta$-(4- $O$-methylglucopyranoside) (6). On the other hand, the broth extract of BCC 9617 contained small amounts of a new naphthopyrone glycoside, rubrofusarin-6-O- $\beta$-(4- $O$-methylglucopyranoside) (7) along with 5. Structures of the new compounds, 6 and 7, were elucidated by interpretation of NMR and mass spectroscopic data. The overall results demonstrated that the metabolite profiles of the cultured anamorph (BCC 9616) and teleomorph (BCC 9617) originating from the same host specimen resemble each other closely. The ${ }^{1} \mathrm{H}-$ NMR spectroscopic analysis of the culture extracts from other strains of $P$. cinnamomeus and T. luteorostrata revealed that zeorin is the most commonly occurring fermentation product of these fungi, whereas paecilodepsipeptide A was the metabolite specific to the particular isolate BCC 9616/BCC 9617.
\end{abstract}

Keywords Paecilomyces cinnamomeus, Torrubiella luteorostrata, paecilodepsipeptide A, chemotaxonomy, zeorin

M. Isaka (Corresaponding author), S. Palasarn, K. Kocharin, N. L. Hywel-Jones: National Center for Genetic Engineering and Biotechnology (BIOTEC), Thailand Science Park, 113 Phaholyothin Road, Klong Luang, Pathumthani 12120, Thailand, E-mail: isaka@biotec.or.th

\section{Introduction}

The fungus Torrubiella luteorostrata is a rarely described scale insect (Homoptera) pathogen within the genus Torrubiella sensu lato. Its association with a Paecilomyces cinnamomeus anamorph was shown for Thai isolates [1]. The potential of such rare species as producers of bioactive compounds is unknown. As part of the research program on the search for bioactive compounds from insect pathogenic fungi [2], we have recently isolated an antimalarial and antitumor cyclohexadepsipeptide, paecilodepsipeptide A (1), its linear minor analogues paecilodepsipeptides B (2) and C (3), and a known hopane triterpene, zeorin (4), from P. cinnamomeus BCC 9616 [3]. These compounds were obtained from the mycelium extract of a liquid-media fermentation [3]. In the present study, constituents of the extract from culture broth (filtrate) were investigated, which led to the isolation of a known diketopiperazine, terezine $\mathrm{D}$ (5) [4], and a new xanthone glycoside, norlichexanthone-6$O$ - $\beta$-(4-O-methylglucopyranoside) (6, Fig. 1). Fortunately, we also have the corresponding teleomorph, $T$. luteorostrata $\mathrm{BCC} 9617$, collected together with the anamorph P. cinnamomeus BCC 9616 on the same host insect specimen. For comparison of the metabolite profiles, BCC 9617 was also subjected to large-scale fermentation, under the same culture conditions as BCC 9616, and chemical investigation was conducted for broth and mycelium extracts. $\mathbf{1}$ and $\mathbf{4}$ were again isolated as the major constituents of the mycelium extract, while the broth extract provided $\mathbf{5}$ and a small amount of a new naphthopyrone glycoside, rubrofusarin-6-O- $\beta$ (4-O-methylglucopyranoside) (7). In addition to these studies, metabolite profiles of several other isolates of 
<smiles>CC(C)=CCOc1ccc(C[C@@H](Cc2ccccc2)NC(=O)[C@H](C)NC(=O)[C@H](Cc2ccc(O)cc2)NC(=O)CNC(=O)[C@H](C)NC(=O)[C@H](Cc2ccccc2)OC(=O)[C@H](C)NC(=O)CNC(=O)C(C)C)cc1</smiles>

1

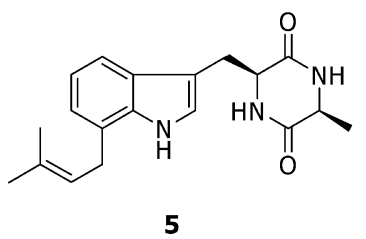<smiles>[R]C[C@@H](O)C(=O)N[C@@H](C)C(=O)NCC(=O)N[C@@H](Cc1ccc(O)cc1)C(=O)N[C@@H](Cc1ccc(OCC=C(C)C)cc1)C(=O)N[C@@H](C)C(=O)N[C@@H](C)Cc1ccc(OCC=C(C)C)cc1</smiles>

$\mathbf{2}: \mathrm{R}=\mathrm{H}$
$\mathbf{3}: \mathrm{R}=\mathrm{CH}_{3}$

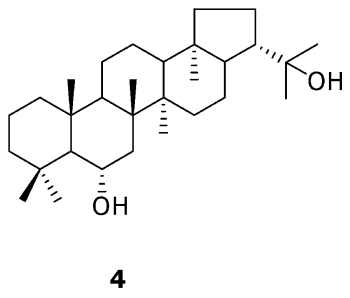

4

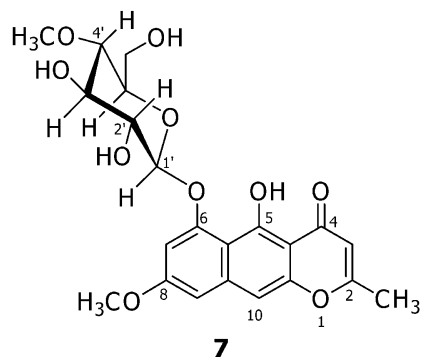

Fig. 1 Structures of the compounds isolated from Paecilomyces cinnamomeus BCC 9616 and/or Torrubiella luteorostrata BCC 9617.

P. cinnamomeus and T. luteorostrata were also briefly examined simply by analysis of ${ }^{1} \mathrm{H}-\mathrm{NMR}$ spectra of the extracts.

\section{Results and Discussion}

The broth extract of P. cinnamomeus BCC 9616 was subjected to Sephadex LH-20 and silica gel column chromatography to furnish 5 (10 mg) and $6(3.0 \mathrm{mg}) .1$ and $4[5,6]$ were detected in the broth extract, but with much less quantity than mycelium extract. The NMR, MS and IR spectroscopic data for $\mathbf{5}$ were identical to those of terezine $\mathrm{D}$, which was previously isolated from the coprophilous fungus Sporormiella teretispora (Pleosporales, Sporormiaceae) [4].

The molecular formula of $\mathbf{6}$ was established as $\mathrm{C}_{21} \mathrm{H}_{22} \mathrm{O}_{10}$ using HRESI-MS in combination with the ${ }^{13} \mathrm{C}$-NMR data. The ${ }^{1} \mathrm{H}$ - and ${ }^{13} \mathrm{C}$-NMR data (DMSO- $d_{6}$ ) suggested that 6 was an aromatic polyketide attached with a sugar. The aglycone was composed of a conjugated ketone resonated at $\delta_{\mathrm{C}} 181.8$, seven quaternary $s p^{2}$ carbons $\left(\delta_{\mathrm{C}} 166.8,163.5\right.$, $161.7,158.9,157.2,143.0,113.3$, and 102.4), two sets of meta-coupled methines, $\delta_{\mathrm{H}} 6.99\left(\delta_{\mathrm{C}} 101.7\right) / \delta_{\mathrm{H}} 6.84\left(\delta_{\mathrm{C}}\right.$ $116.9)$ and $\delta_{\mathrm{H}} 6.26\left(\delta_{\mathrm{C}} 94.0\right) / \delta_{\mathrm{H}} 6.11\left(\delta_{\mathrm{C}} 98.8\right)$, and a methyl group $\left(\delta_{\mathrm{H}} 2.77, \mathrm{~s} ; \delta_{\mathrm{C}} 23.4\right)$ attached to an aromatic ring. In addition, ${ }^{1} \mathrm{H}$ resonance of a chelated phenolic proton was observed at $\delta_{\mathrm{H}}$ 13.27. Interpretation of the HMBC correlations (Fig. 2) revealed that the aglycone moiety was norlichexanthone (8-methyl-1,3,6-trihydroxy-

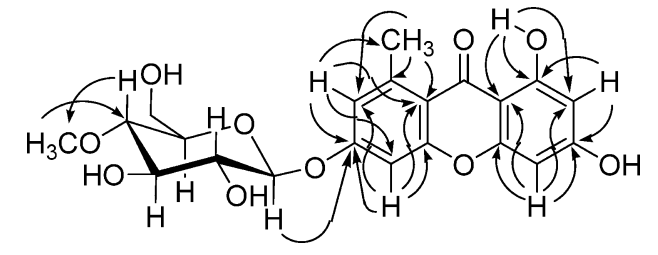

Fig. 2 Selected HMBC correlations for norlichexanthone6-O- $\beta$-(4-O-methylglucopyranoside) (6).

xanthone) [7]. The sugar moiety was assigned as $4^{\prime}-O$ methyl- $\beta$-glucopyranose. Thus, the vicinal coupling constants of $J_{1^{\prime}, 2^{\prime}}=7.8 \mathrm{~Hz}, \quad J_{2^{\prime}, 3^{\prime}}=9.1 \mathrm{~Hz}, \quad$ and $J_{3^{\prime}, 4^{\prime}}=J_{4^{\prime}, 5^{\prime}}=9.3 \mathrm{~Hz}$, clearly indicated that $\mathrm{H}-1$ to $\mathrm{H}-5$ were all placed on axial positions. Intense $\mathrm{HMBC}$ correlation from methoxy protons $\left(\delta_{\mathrm{H}} 3.47,3 \mathrm{H}, \mathrm{s}\right)$ to $\mathrm{C}-4$ ' and the correlation from $\mathrm{H}-4^{\prime}$ to the methoxy carbon $\left(\delta_{\mathrm{C}} 60.1\right)$ demonstrated that the $4^{\prime}$-hydroxyl group was methylated. The linkage of the sugar to the xanthone was evident from the HMBC correlation from the anomeric proton $\left(\mathrm{H}-1^{\prime}, \delta_{\mathrm{H}}\right.$ $5.14)$ to $\mathrm{C}-6\left(\delta_{\mathrm{C}} 161.7\right)$. The NOESY correlation found between $\mathrm{H}-5$ and $\mathrm{H}-\mathrm{1}^{\prime}$ further supported the sugar junction. On the basis of these data, 6 was designated as norlichexanthone-6-O- $\beta$-(4- $O$-methylglucopyranoside). Because of the sample shortage, acid hydrolysis of $\mathbf{6}$ was not conducted.

The teleomorph, T. luteorostrata BCC 9617 was cultured under the same scale (5.0 liters) and conditions as $P$. cinnamomeus BCC 9616. The mycelium extract was mainly composed of $\mathbf{4}$ and $\mathbf{1}$, similar to the constituent of the BCC 9616 mycelium extract. A small amount of 2 
(10 mg) was obtained, while 3 was not purified due to the very low concentration in the complex mixture. These were probably isolation artefacts produced by hydrolysis or methanolysis of $\mathbf{1}$ during the column chromatography or in the methanolic extraction of mycelia. Upon examination of further purification of $\mathbf{1}$ by trituration in $\mathrm{MeOH}$, we also observed partial transformations to $\mathbf{2}$ and $\mathbf{3}$.

The extract from BCC 9617 broth was subjected to chromatographic fractionations using Sephadex LH20, silica gel and preparative HPLC (ODS column) to furnish $\mathbf{5}$ $(5.6 \mathrm{mg})$ and a new naphthopyrone glycoside $7(3.6 \mathrm{mg})$. The molecular formula of $7, \mathrm{C}_{22} \mathrm{H}_{24} \mathrm{O}_{10}$, was determined by HRESI-MS. The ${ }^{1} \mathrm{H}$ - and ${ }^{13} \mathrm{C}-\mathrm{NMR}$ data suggested that 7 was an aromatic polyketide glycoside, but the aglycone moiety was very different from 6. Analysis of NMR spectroscopic data revealed the naphthopyrone structure of the aglycone to be identical with rubrofusarin (Fig. 3). The sugar moiety of 7 was also elucidated on the basis of NMR data, and it was identical to that of $\mathbf{6}$. The linkage of the sugar to the aglycone was indicated by the HMBC correlation from $\mathrm{H}-\mathrm{1}^{\prime}$ to $\mathrm{C}-6$, which was also supported by the NOESY cross-peaks between H-7 and H-1'. A closely related compound, rubrofusarin-6- $O-\beta$-D-glucopyranoside, was previously isolated from the plants Cassia pudibunda [8] and C. quinquangulata [9]. 7 is its $4^{\prime}$-O-methyl derivative.

Taken together, it was concluded that the major chemical constituents of the anamorph, P. cinnamomeus BCC 9616, and those of the teleomorph, T. luteorostrata BCC 9617 are the same, although some differences were found in minor components. Since the differences between BCC 9616 and BCC 9617 is related to the life-cycle (asexual in the former, sexual in the latter), it is not unreasonable to assume that the profiles of the cell cultures by liquid-media fermentation should be identical. However, it is considered worth reporting here, because such comparisons have rarely been performed. Importantly, it also suggests that these metabolites are not dependent on the sexual form of the life-cycle but are involved in more general aspects of the function of the pathogen.

Given the evidence of the similarity of the metabolite profiles of P. cinnamomeus/T. luteorostrata within the same isolate, we compared the metabolites of different isolates. Several isolates of P. cinnamomeus (4 strains; BCC 7826, BCC 14491, BCC 18640, BCC 18642) and T. luteorostrata (5 strains; BCC 1419, BCC 7630, BCC 7841, BCC 12904, BCC 14522), collected at various locations in Thailand, were cultured using $250 \mathrm{ml}$ of liquid medium for each strain, and the extracts from mycelium and broth were analyzed by ${ }^{1} \mathrm{H}-\mathrm{NMR}(400 \mathrm{MHz})$. None of these extracts contained 1. In contrast, 4 was detected in all mycelia

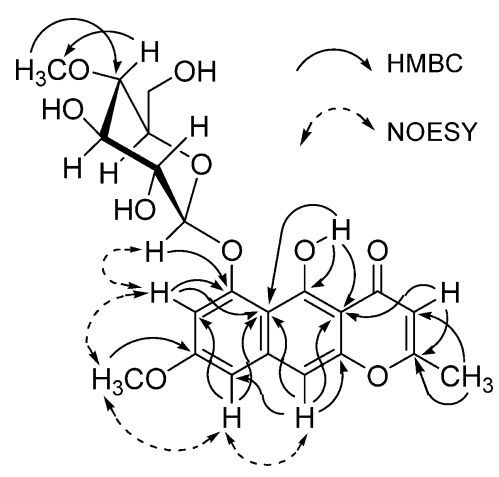

Fig. 3 Selected HMBC and NOESY cross-peaks for rubrofusarin-6-O- $\beta$-(4-O-methylglucopyranoside) (7).

extracts, with only one non-production case in $T$. luteorostrata $\mathrm{BCC} 14522$. These results indicate that $\mathbf{1}$ is specific to BCC 9616/BCC 9617, whereas zeorin was the commonly-occurring metabolite of $P$. cinnamomeus $/ T$. luteorostrata throughout Thailand. It should also be reported that similar NMR studies for other species of Paecilomyces (21 strains) and Torrubiella (12 strains) did not show any example of zeorin production. Zeorin $(6 \alpha, 22-$ dihydroxyhopane) has been isolated from lichens [10, 11], liverworts [12 14], and higher plants [15 18], but, it is not a commonly occurring fungal metabolite. In our chemical studies on the fungal metabolites, we noticed very frequent occurrence of zeorin in species of Hypocrella and their anamorph Aschersonia (unpublished result), both of which are also exclusive scale-insect pathogens. Although belonging to the same family, Clavicipitaceae, the species $P$. cinnamomeus/T. luteorostrata are taxonomically (morphology, phylogenetics) rather far from the genera HypocrellalAschersonia having affinities with the common insect pathogen Metarhizium. The specificity of zeorin found in P. cinnamomeus/T. luteorostrata compared with other members of the genus Paecilomyces sensu lato [19, 20] indicates that the metabolite could be used as a chemotaxonomic marker. In this context, we are currently planning the correlation with phylogenetic data.

\section{Experimental}

\section{General}

Optical rotations were measured with a JASCO P-1030 digital polarimeter. UV spectra were recorded on a Varian CARY 1E UV-visible spectrophotometer. FT-IR spectra were recorded on a Bruker VECTOR 22 spectrometer. NMR spectra were recorded on a Bruker AV500D spectrometer. ESI-TOF mass spectra were measured with a Micromass LCT mass spectrometer. 


\section{Fungal Material}

P. cinnamomeus (BCC 9616) was isolated by collecting conidia on a small block ( $c a .0 .5 \mathrm{~mm}$ ) of fresh Potato Dextrose Agar (PDA) and transferring to a sterile petri plate of PDA. T. luteorostrata (BCC 9617) ascospores from the same specimen were isolated by allowing the ascospores to discharge over a sterile petri plate of PDA. The host was a scale insect (Homoptera-Aleyrodidae) collected in Khao Yai National Park, Nakorn Nayok province, Thailand on July 18, 2001 from the underside of a dicotyledonous leaf. These isolates were deposited in the BIOTEC Culture Collection (BCC) as BCC 9616 and BCC 9617, respectively, on August 3, 2001.

\section{Fermentation of BCC 9616 and Isolation}

P. cinnamomeus BCC 9616 was maintained on PDA at $25^{\circ} \mathrm{C}$, the agar was cut into plugs $(1 \times 1 \mathrm{~cm})$ and inoculated into $2 \times 250-\mathrm{ml}$ Erlenmeyer flasks containing $25 \mathrm{ml}$ of potato dextrose broth (PDB; potato starch $4.0 \mathrm{~g}$ and dextrose $20 \mathrm{~g}$ in 1 liter of distilled water). After incubation at $25^{\circ} \mathrm{C}$ for 8 days on a rotary shaker $(200 \mathrm{rpm})$, each primary culture was transferred into a 1-liter Erlenmeyer flask containing $250 \mathrm{ml}$ of the same liquid medium (PDB), and incubated at $25^{\circ} \mathrm{C}$ for 8 days on a rotary shaker (200 rpm). Each $25 \mathrm{ml}$ portion of the secondary cultures (in 2 flasks) was transferred into $20 \times 1$-liter Erlenmeyer flasks each containing $250 \mathrm{ml}$ of a liquid medium (composition, sucrose $30 \mathrm{~g}$, malt extract $20 \mathrm{~g}$, bacto-peptone $2.0 \mathrm{~g}$, yeast extract $1.0 \mathrm{~g}, \mathrm{KCl} 0.5 \mathrm{~g}, \mathrm{MgSO}_{4} \cdot 7 \mathrm{H}_{2} \mathrm{O} 0.5 \mathrm{~g}$ and $\mathrm{KH}_{2} \mathrm{PO}_{4}$ $0.5 \mathrm{~g}$ in 1 liter of distilled water), and final fermentation was carried out at $25^{\circ} \mathrm{C}$ for 24 days under static conditions. The cultures were filtered to separate mycelium (residue) and filtrate. The filtrate was extracted with EtOAc $(2 \times 3.5$ liters), and the organic layer was evaporated to dryness to leave a pale brown gum (broth extract; $321 \mathrm{mg}$ ). The mycelium was macerated in $\mathrm{MeOH}$ (1 liter, 2 days) and filtered. The filtrate was defatted with hexane $(700 \mathrm{ml})$ and the $\mathrm{MeOH}$ phase was evaporated to dryness. The residue was diluted with EtOAc $(700 \mathrm{ml})$, washed with $\mathrm{H}_{2} \mathrm{O}$ $(200 \mathrm{ml})$, concentrated under reduced pressure to leave a pale brown gum (mycelium extract, $8.20 \mathrm{~g}$ ). Isolation of $\mathbf{1}$ $(174 \mathrm{mg})$ and zeorin (major constituent) from the mycelium extract was previously reported [3]. The broth extract (321 mg) was passed through a column on Sephadex LH20 $(2.8 \times 60 \mathrm{~cm})$ and eluted with $\mathrm{MeOH}$. The fractions, Fr-4 and Fr-5, eluted after zeorin (Fr-2) and depsipeptides (Fr$2,3)$, were combined $(100 \mathrm{mg})$ and it was repeatedly subjected to silica gel column chromatography (aqueous $\mathrm{NH}_{4} \mathrm{OH} / \mathrm{MeOH} / \mathrm{CH}_{2} \mathrm{Cl}_{2}$; step gradient elution) to furnish $\mathbf{5}$ $(10 \mathrm{mg})$ and $\mathbf{6}(3.0 \mathrm{mg})$.

6: colorless amorphous solid; $[\alpha]_{\mathrm{D}}^{25}-27$ (c) 0.38 ,
$\mathrm{MeOH}) ; \mathrm{UV}(\mathrm{MeOH}) \lambda_{\max }(\log \varepsilon) 203$ (4.06), 241 (4.06), 253 (sh, 3.84), 307 (3.78), 348 (sh, 3.29) nm; IR (KBr) $v_{\max }$ $3480 \sim 3200,1655,1620,1281,1091,828 \mathrm{~cm}^{-1}$; ${ }^{1} \mathrm{H}-\mathrm{NMR}$ $\left(500 \mathrm{MHz}, \mathrm{DMSO}-d_{6}\right) \delta 13.27(1 \mathrm{H}, \mathrm{s}, 1-\mathrm{OH}), 6.99(1 \mathrm{H}, \mathrm{d}$, $J=2.2 \mathrm{~Hz}, \mathrm{H}-5), 6.84(1 \mathrm{H}$, br s, H-7) $6.26(1 \mathrm{H}, \mathrm{d}$, $J=1.4 \mathrm{~Hz}, \mathrm{H}-4), 6.11(1 \mathrm{H}, \mathrm{d}, J=1.5 \mathrm{~Hz}, \mathrm{H}-2), 5.14(1 \mathrm{H}, \mathrm{d}$, $\left.J=7.8 \mathrm{~Hz}, \mathrm{H}-1^{\prime}\right), 3.65\left(1 \mathrm{H}\right.$, br d, $J=10.4 \mathrm{~Hz}$, Ha- $\left.6^{\prime}\right), 3.53$ $\left(1 \mathrm{H}, \mathrm{m}, \mathrm{H}-5^{\prime}\right), 3.52\left(1 \mathrm{H}, \mathrm{m}, \mathrm{Hb}-6^{\prime}\right), 3.47\left(3 \mathrm{H}, \mathrm{s}, 4^{\prime}-\mathrm{OCH}_{3}\right)$, $3.45\left(1 \mathrm{H}, \mathrm{t}, J=9.1 \mathrm{~Hz}, \mathrm{H}-3^{\prime}\right), 3.29(1 \mathrm{H}, \mathrm{dd}, J=8.6,8.3 \mathrm{~Hz}$, H-2'), $3.06\left(1 \mathrm{H}, \mathrm{t}, J=9.3 \mathrm{~Hz}, \mathrm{H}-4^{\prime}\right), 2.77\left(3 \mathrm{H}, \mathrm{s}, 8-\mathrm{CH}_{3}\right)$; ${ }^{13} \mathrm{C}-\mathrm{NMR}\left(125 \mathrm{MHz}, \mathrm{DMSO}-d_{6}\right) \delta 181.8$ (s, C-9), 166.8 (s, C-3), 163.5 (s, C-1), 161.7 (s, C-6), 158.9 (s, C-10a), 157.2 (s, C-4a), 143.0 (s, C-8), 116.9 (d, C-7), 113.3 (s, C-8a), 102.4 (s, C-9a), 101.7 (d, C-5), 99.9 (d, C-1'), 98.8 (d, C-2), 94.0 (d, C-4), 79.4 (d, C-4'), 76.6 (d, C-3'), 76.2 (d, C-5'), 73.8 (d, C-2'), 60.7 (t, C-6'), 60.1 (q, 4'-OCH 4 $\left._{3}\right), 23.4$ (q, 8- $\mathrm{CH}_{3}$ ); HRMS (ESI-TOF) $\mathrm{m} / z$ 435.1289 $[\mathrm{M}+\mathrm{H}]^{+}$(calcd for $\mathrm{C}_{21} \mathrm{H}_{23} \mathrm{O}_{10}, 435.1291$ ).

\section{Fermentation of BCC 9617 and Isolation}

T. luteorostrata BCC 9617 was cultured under the same conditions and scale with those for BCC 9616 described above. Filtration and extractions afforded broth extract $(1.12 \mathrm{~g})$ and mycelial extract $(8.20 \mathrm{~g})$. The broth extract was fractionated by passing through Sephadex LH20 column and eluted with $\mathrm{MeOH}$. The second fraction $(120 \mathrm{mg})$ was repeatedly fractionated by silica gel column chromatography (aqueous $\mathrm{NH}_{4} \mathrm{OH} / \mathrm{MeOH} / \mathrm{CH}_{2} \mathrm{Cl}_{2}$; step gradient elution) and preparative HPLC using a reversedphase column (NovaPak $\mathrm{HRC}_{18}, 25 \times 100 \mathrm{~mm}, 6 \mu \mathrm{m}$ ) and elution with $\mathrm{MeCN} / \mathrm{H}_{2} \mathrm{O}=30: 70(8 \mathrm{ml} /$ minute $)$ to furnish 7 (3.6 mg, $t_{\mathrm{R}} 5.0$ minutes) and $5\left(5.6 \mathrm{mg}, t_{\mathrm{R}} 6.5\right.$ minutes). The mycelial extract $(8.20 \mathrm{~g})$ was subjected to column chromatography on silica gel $(6 \times 20 \mathrm{~cm}$, step gradient elution, $\mathrm{MeOH} / \mathrm{CH}_{2} \mathrm{Cl}_{2}$ ) to obtain seven fractions; $\mathrm{Fr}-1$ (1.24 g), Fr-2 (548 mg), Fr-3 (683 mg), Fr-4 (1.03 g), Fr-5 (616 mg), Fr-6 (118 mg), and Fr-7 (1.05 g). Fr-1 and Fr-2 were combined and further fractionated by $\mathrm{CC}$ on silica gel $\left(4 \times 20 \mathrm{~cm}\right.$, step gradient elution, $\left.\mathrm{MeOH} / \mathrm{CH}_{2} \mathrm{Cl}_{2}\right)$ to furnish pure zeorin $(237 \mathrm{mg})$ and a mixture mainly composed of zeorin $(1.42 \mathrm{~g})$. Fr-4 was further purified by $\mathrm{CC}$ on silica gel $\left(3.8 \times 20 \mathrm{~cm}\right.$, step gradient elution with $\left.\mathrm{MeOH} / \mathrm{CH}_{2} \mathrm{Cl}_{2}\right)$ to furnish $\mathbf{1}(889 \mathrm{mg})$. A small amount of $\mathbf{2}(10.1 \mathrm{mg})$ was obtained from $\mathrm{Fr}-6$ by silica gel column chromatography $\left(2.8 \times 20 \mathrm{~cm}\right.$, step gradient elution with $\left.\mathrm{MeOH} / \mathrm{CH}_{2} \mathrm{Cl}_{2}\right)$.

7: yellow powder; $[\alpha]_{\mathrm{D}}^{27}-88(c \quad 0.09, \mathrm{MeOH})$; UV $(\mathrm{MeOH}) \lambda_{\max }(\log \varepsilon) 223$ (4.32), 252 (sh, 4.26), 276 (4.49), $399(3.65) \mathrm{nm}$; IR (KBr) $v_{\max } 3445,1657,1626,1581$, $1111,1049 \mathrm{~cm}^{-1}$; ${ }^{1} \mathrm{H}-\mathrm{NMR}\left(500 \mathrm{MHz}\right.$, acetone- $\left.d_{6}\right) \delta 15.34$ $(1 \mathrm{H}, \mathrm{s}, 5-\mathrm{OH}), 7.17(1 \mathrm{H}, \mathrm{s}, \mathrm{H}-10), 6.96(1 \mathrm{H}, \mathrm{d}, J=2.3 \mathrm{~Hz}$, H-9), 6.89 (1H, d, $J=2.3 \mathrm{~Hz}, \mathrm{H}-7), 6.12$ (1H. q, $J=0.5 \mathrm{~Hz}$, 
H-3), $4.96\left(1 \mathrm{H}, \mathrm{d}, J=7.5 \mathrm{~Hz}, \mathrm{H}-1^{\prime}\right), 4.43(1 \mathrm{H}, \mathrm{d}, J=4.0 \mathrm{~Hz}$, $\left.3^{\prime}-\mathrm{OH}\right), 4.32\left(1 \mathrm{H}, \mathrm{d}, J=2.2 \mathrm{~Hz}, 2^{\prime}-\mathrm{OH}\right), 3.91(3 \mathrm{H}, \mathrm{s}, 8-$ $\left.\mathrm{OCH}_{3}\right), 3.92\left(1 \mathrm{H}, \mathrm{m}, \mathrm{Ha}-6^{\prime}\right), 3.89\left(1 \mathrm{H}, \mathrm{m}, 6^{\prime}-\mathrm{OH}\right), 3.74$ $\left(1 \mathrm{H}, \mathrm{m}, \mathrm{Hb}-6^{\prime}\right), 3.68\left(1 \mathrm{H}, \mathrm{dt}, J=3.8,9.8 \mathrm{~Hz}, \mathrm{H}-3^{\prime}\right), 3.62$ $\left(1 \mathrm{H}, \mathrm{ddd}, J=9.5,7.5,2.1 \mathrm{~Hz}, \mathrm{H}-2^{\prime}\right), 3.58\left(1 \mathrm{H}, \mathrm{m}, \mathrm{H}-5^{\prime}\right)$, $3.57\left(3 \mathrm{H}, \mathrm{s}, 4^{\prime}-\mathrm{OCH}_{3}\right), 3.26\left(1 \mathrm{H}\right.$, ddd, $\left.J=9.6,8.7 \mathrm{~Hz}, \mathrm{H}-4^{\prime}\right)$, $2.42\left(3 \mathrm{H}\right.$, br s, $\left.2-\mathrm{CH}_{3}\right) ;{ }^{13} \mathrm{C}-\mathrm{NMR}\left(125 \mathrm{MHz}\right.$, acetone- $\left.d_{6}\right) \delta$ 184.4 (s, C-4), 168.9 (s, C-2), 162.1 (s, C-5), 161.5 (s, C8), 158.5 (C-6), 153.1 (s, C-10a), 140.8 (s, C-9a), 108.5 (s, C-5a), 106.7 (d, C-3), 104.3 (s, C-4a), 103.33 and 103.26 (d $\times 2, C-7$ and C-1'), 101.3 (d, C-10), 100.5 (d, C-9), 79.3 (d, C-4'), 76.6 and $76.4\left(\mathrm{~d} \times 2, \mathrm{C}-3^{\prime}\right.$ and C-5'), 74.5 (d, C2'), 61.4 (t, C-6'), 59.7 (q, 4'-OCH ${ }_{3}$ ), 55.1 (q, 8- $\mathrm{OCH}_{3}$ ), 19.7 (q, 2- $\mathrm{CH}_{3}$ ); HRMS (ESI-TOF) $\mathrm{m} / \mathrm{z} 449.1452[\mathrm{M}+\mathrm{H}]^{+}$ (calcd for $\mathrm{C}_{22} \mathrm{H}_{25} \mathrm{O}_{10}, 449.1447$ ).

Acknowledgments Financial support from the Bioresources Research Network, National Center for Genetic Engineering and Biotechnology, is gratefully acknowledged. M.I. thanks the Thailand Research Fund for the research grant (BRG 4880011).

\section{References}

1. Hywel-Jones NL. Torrubiella luteorostrata a pathogen of scale insects and its association with Paecilomyces cinnamomeus with a note on Torrubiella tenuis. Mycol Res 97: 1126-1130 (1993)

2. Isaka M, Kittakoop P, Kirtikara K, Hywel-Jones NL, Thebtaranonth Y. Bioactive substances from insect pathogenic fungi. Acc Chem Res 38: 813-823 (2005)

3. Isaka $\mathrm{M}$, Palasarn $\mathrm{S}$, Lapanun $\mathrm{S}$, Sriklung $\mathrm{K}$. Paecilodepsipeptide A, an antimalarial and antitumor cyclohexadepsipeptide from the insect pathogenic fungus Paecilomyces cinnamomeus BCC 9616. J Nat Prod 70: 675-678 (2007)

4. Wang Y, Gloer JB, Scott JA, Malloch D. Terezines A D: new amino acid-derived bioactive metabolites from the coprophilous fungus Sporormiella teretispora. J Nat Prod 58: 93-99 (1995)

5. Tsuda Y, Isobe K, Fukushima S, Ageta H, Iwata K. Final clarification of the saturated hydrocarbons derived from hydroxyhopane, diploptene, zeorin, and dustanin. Tetrahedron Lett 23-28 (1967)

6. Yoshioka I, Nakanishi T, Kitagawa I. The chemical proof of hopane skeleton of zeorin. Chem Pharm Bull 15: 353-355 (1967)

7. Sundholm EG. Chemical studies on lichens. 34. Total synthesis of lichen xanthones. Revision of structures. Tetrahedron 34: 577-586 (1978)

8. Messana I, Ferrari F, Cavalcanti MSB, Morace G. An anthraquinone and three naphthopyrone derivatives from Cassia pudibunda. Phytochemistry 30: 708-710 (1991)

9. Li X-C, Dunbar DC, ElSohly HN, Jacob MR, Nimrod AC, Walker LA, Clark AM. A new naphthopyrone derivative from Cassia quinquangulata and structural revision of quinquangulin and its glycosides. J Nat Prod 64: 1153-1156 (2001)

10. Yoshioka I, Yamaki M, Kitagawa I. On the triteroene constituents of a lichen, Parmelia entomheiochroa Hue.; zeorin, leucotylin, leucotylic acid, and five new related triterpenoids. Chem Pharm Bull 14: 804-807 (1966)

11. Shibata S, Furuya T, Iizuka H. Gas-liquid chromatography of lichen substances. I. Studies on zeorin. Chem Pharm Bull 13: 1254-1257 (1965)

12. Toyota M, Asakawa Y. Sesqui- and triterpenoids of the liverwort Conocephalum japonicum. Phytochemistry 32: 1235-1237 (1993)

13. Bardon A, Kamiya N, Toyota M, Takaoka, S, Asakawa Y. Sesquiterpenoids, hopanoids and bis(bibenzyls) from the Argentine liverwort Plagiochasma rupestre. Phytochemistry 52: 1323-1329 (1999)

14. Bardona A, Mitre GB, Kamiya N, Toyota M, Asakawa Y. Eremophilanolides and other constituents from the Argentine liverwort Frullania brasiliensis. Phytochemistry 59: 205-213 (2002)

15. Shiojima K, Ageta H. Fern constituents: triterpenoids isolated from the leaves of Adiantum edgeworthii. Structures of 19-hydroxyadiantone and fern-9(11)-en-25-oic acid. Chem Pharm Bull 42: 45-47 (1994)

16. Wu F-E, Koike K, Nikaido T, Ishii K, Ohmoto T, Ikeda K. Terpenoids and flavonoids from Arenaria kansuensis. Chem Pharm Bull 38: 2281-2282 (1990)

17. Inayama S, Hori H, Pang G-M, Nagasawa H, Ageta H. Isolation of a hopane-type triterpenoid, zeorin, from a higher plant, Tripterygium regelii. Chem Pharm Bull 37: 2836-2837 (1989)

18. Wong SM, Oshima Y, Pezzuto JM, Fong HH, Farnsworth NR. Plant anticancer agents XXXIX: triterpenes from Iris missouriensis (Iridaceae). J Pharm Sci 75: 317-320 (1986)

19. Luangsa-ard JJ, Hywel-Jones NL, Samson RA. The polyphyletic natures of Paecilomyces sensu lato based on 18S-generated rDNA phylogeny. Mycologia 96: 773-780 (2004)

20. Luangsa-ard JJ, Hywel-Jones NL, Manoch L, Samson RA. On the relationship of Paecilomyces sect. Isarioidea species. Mycol Res 109: 581-589 (2005) 